\title{
SISTEM KESANTUNAN SERTA REFLEKSI BUDAYA DARI KOMUNITAS ORANG TUA MURID TIONGHOA SURABAYA DI TBI SURABAYA
}

\author{
Robby Andre \\ TBI (The British Institute) Surabaya \\ email@robbyandre.my.id
}

\begin{abstract}
This study examines the prevailing politeness system in the Tionghoa parent community students in TBI (The British Institute) Surabaya and the cultural reflection that can be seen from the use of language in the community. The method that was applied in this research is qualitative method. Sources of data in this study were taken from conversation recordings among the informants. Meanwhile, the theory used in the research was the theory of politeness system formulated by Scollon and Scollon (2001). The results of this study indicated that the system of politeness adopted by the Tionghoa parent community of students in TBI Surabaya was a system of solidarity politeness. In this system of politeness there was no difference in distance and power among members of the community. In addition, the Tionghoa parent community in TBI Surabaya also had a distinctive feature of using the language; there was a mixing of Javanese Ngoko, Indonesian and Hokkien dialect, Mandarin as linguistic markers that distinguished their language use from the indigenous people of Surabaya. Moreover, cultural reflection resulting from the use of mixed language between Javanese Ngoko and Hokkien dialect showed that there is an egalitarian system applied in the community.
\end{abstract}

Key Words: Chinese ethnics, politeness system,, Bahasa Jawa Ngoko, Hokkien dialect, culture

\begin{abstract}
Abstrak
Penelitian ini mengkaji tentang sistem kesantunan yang berlaku di dalam komunitas orang tua murid Tionghoa Surabaya di TBI (The British Institute) Surabaya serta refleksi budaya yang dapat dilihat dari penggunaan bahasa yang terjadi di komunitas tersebut. Metode yang diterapkan dalam penelitian adalah metode kualitatif. Sumber data dari penelitian ini diambil dari perekaman percakapan di antara para informan tersebut. Sedangkan teori yang digunakan dalam penelitian adalah teori sistem kesantunan yang dirumuskan oleh Scollon dan Scollon (2001). Hasil dari penelitian ini menyatakan bahwa sistem kesantunan yang dianut oleh komunitas orang tua murid Tionghoa Surabaya di TBI Surabaya adalah sistem kesantunan solidaritas. Dalam system kesantunan ini tidak terdapat perbedaan jarak dan kuasa di antara anggota komunitasnya. Selain itu, komunitas orang tua murid Tionghoa Surabaya di TBI Surabaya juga memiliki ciri khas dalam menggunakan bahasanya, terdapat pencampuran antara bahasa Jawa Ngoko, bahasa Indonesia dan dialek Hokkien, Mandarin sebagai pemarkah linguistik yang membedakan penggunaan bahasa mereka dengan masyarakat asli Surabaya. Sedangkan refleksi budaya yang dihasilkan dari penggunaan bahasa campuran antara bahasa Jawa Ngoko dengan dialek Hokkien menunjukkan bahwa adanya sistem egaliter yang diterapkan dalam komunitas tersebut.
\end{abstract}

Kata Kunci: Etnik Tionghoa Surabaya, Sistem Kesantunan, Bahasa Jawa Ngoko, Dialek Hokkien, Budaya 


\section{PENDAHULUAN}

Bahasa merupakan sarana komunikasi dalam interaksi sosial di masyarakat yang melibatkan satu individu dengan individu yang lain. Dengan bahasa, seorang penutur akan dengan mudah mampu menyampaikan sebuah pesan kepada mitra tuturnya. Dalam hal ini, penyampaian pesan harus melibatkan norma-norma kesantunan yang berlaku di dalam masyarakat tertentu. Apabila norma-norma kesantunan tersebut tidak diperhatikan atau diacuhkan, maka bukan tidak mungkin bagi si penutur bahasa tersebut akan mengalami banyak kendala dalam praktik komunikasinya.

Berkaitan dengan penerapan norma/sistem kesantunan yang berlaku di masyarakat, hal ini pada dasarnya memiliki sifat yang umum. Namun, cara para penutur bahasa yang terdapat dalam suatu masyarakat tertentu memiliki penerapan yang berbeda-beda dalam mewujudkan kesantunan komunikasi tersebut. Dalam hal ini, peneliti sangat tertarik untuk mengkaji sistem kesantunan yang ada di Indonesia. Di dalamnya terdapat banyak sekali etnik dengan latar belakang kebahasaan yang berbeda-beda pula. Bukan tidak mungkin dengan adanya perbedaan etnik yang ada di Indonesia, cara penerapan sistem kesantunan dari satu etnik ke etnik yang lain juga memiliki sistem atau tata cara yang berbeda pula. Terkait dengan penerapan sistem kesantunan yang berada dalam suatu komunitas bahasa, kita juga dapat melihat bagaimana penggunaan bahasa tersebut dapat merefleksikan nilai-nilai budaya yang berlaku di masyarakat penutur bahasa tersebut.

Oleh karena itu, dalam tulisan ini peneliti tertarik untuk mengkaji sistem kesantunan serta refleksi budaya yang tercermin dari penggunaan bahasa dari etnik Tionghoa yang berada di Surabaya, terkhususnya dalam penerapan praktik komunikasi di komunitas orang tua murid di TBI (The British Institute) Surabaya yang mayoritas memiliki latar belakang kebahasaan yang sama. Secara historis, masyarakat Tionghoa Surabaya sudah ada sejak berabad-abad di Surabaya sejak kota ini masih menjadi suatu bagian kerajaan. Dalam bukunya, Nooradjanah (2004) mengatakan oleh karena kondisi terjadi banyak sekali bencana alam dan kelaparan serta serangan yang dialami oleh bangsa Tiongkok, akhirnya memaksa mereka untuk meninggalkan tanah airnya dan salah satu tempat tujuan mengungsi mereka pada waktu itu adalah Surabaya.

Seiring berjalannya waktu, masyarakat Tionghoa yang bermukim di Surabaya berhasil merubah nasibnya dan merubah status sosialnya yang awal hanya menjadi pedagang kecil menjadi masyarakat yang memiliki status sosial yang cukup tinggi dibandingkan dengan masyarakat pribumi pada saat itu (Noordjanah, 2004). Secara status sosial, mereka mampu menduduki posisi dominan di masyarakat meskipun secara kuantitas mereka masih merupakan kaum minoritas di Surabaya.

Dalam praktik komunikasinya, masyarakat Tionghoa di Surabaya memiliki 
pemarkah-pemarkah khusus yang akhirnya dapat mencerminkan identitas mereka sebagai masyarakat Tionghoa. Dalam komunikasi sehari-hari, seringkali terjadi peleburan antara penggunaan bahasa Jawa, bahasa Indonesia dan bahasa Mandarin. Hal ini kemudian menjadi menarik ketika masyarakat Tinghoa sebagai masyarakat minoritas akhirnya mampu mengidentifikasikan diri mereka melalui penggunaan variasi bahasa dominan seperti bahasa Jawa atau bahasa Indonesia yang kemudian digabungkan dengan bahasa Mandarin atau variasi dialek bahasa mereka seperti Hokkien.

Terkait dengan sistem kesantunan sendiri, penggunaan atau penerapan sistem kesantunan masyarakat Tionghoa di Surabaya menjadi menarik untuk dikaji lebih lanjut mengingat adanya peleburan variasi bahasa antara bahasa Jawa, bahasa Indonesia dan bahasa Mandarin atau variasi dialek bahasa Mandarin seperti Hokkien ke dalam praktik komunikasi masyarakat ini sehari-hari. Selain itu, perwujudan sistem kesantunan yang diterapkan oleh masyarakat Tionghoa di Surabaya dirasa juga memiliki suatu kecenderungan. Apakah kemudian masyarakat Tionghoa di Surabaya ini akan mengikuti sistem kesantunan yang ada dalam bahasa Jawa sebagai variasi bahasa yang dominan ataukah masyarakat ini cenderung menciptakan sistem kesantunan sendiri yang dapat dibedakan dari sistem kesantunan bahasa Jawa sebagai variasi bahasa dominan mereka. Selanjutnya, bilamana penggunaan bahasa dari komunitas penutur Tionghoa Surabaya memiliki pola khusus maka secara tidak langsung penggunaan tersebut dapat merefleksikan budaya-budaya yang ada dalam masyarakat tersebut. Berdasarkan latar belakang yang telah disampaikan, maka ada tiga hal penting yang akan dipaparkan di dalam tulisan ini, yaitu mengenai (a) penerapan strategi kesantunan yang digunakan oleh komunitas orang tua murid Tionghoa Surabaya di TBI (The British Institute) Surabaya, (b) kecenderungan sistem kesantunan yang dianut oleh komunitas orang tua murid Tionghoa Surabaya di TBI Surabaya dan (c) bentuk-bentuk penggunaan bahasa apa saja yang merefleksikan budaya-budaya yang dianut oleh komunitas orang tua murid Tionghoa Surabaya di TBI Surabaya.

Terkait dengan fenomena bahasa masyarakat Tionghoa di Indonesia, terdapat beberapa penelitian yang telah dilakukan dalam mengkaji fenomana ini. Sartini (2007) telah melakukan penelitian tentang varietas bahasa Cina di Surabaya. Sedangkan, Jauhari \& Susanto (2014) melakukan penelitian tentang realisasi kesantunan positif masyarakat etnik Tionghoa di Surakarta. Dari dua penelitian tersebut, belum ada yang menaruh perhatian secara khusus kepada aspek kesantunan komunikasi masyarakat Tionghoa di Surabaya serta penggunaan bahasa dari masyarakat Tionghoa Surabaya sebagai bentuk refleksi budaya yang dianut oleh masyarakat tersebut. Oleh karena itu, guna memberikan perbedaan diantara tujuan dua penelitian sebelumnya dengan 
penelitian ini, penulis akan lebih menitikberatkan fokus penelitian ini kepada sistem kesantunan yang diterapkan oleh komunitas orang tua murid Tionghoa Surabaya di TBI Surabaya serta bentuk-bentuk penggunaan dari bahasa mereka sebagai refleksi budaya dari masyarakat Tionghoa Surabaya. Selain itu, penelitian ini menjadi penting untuk dilakukan karena penelitian ini dapat memperkaya dan memberikan kontribusi terhadap bidang ilmu pragmatik dimana praktek kesantunan dari suatu komunitas dapat merefleksikan kebudayaan yang dianut oleh komunitas penutur tersebut. Dalam hal ini, penelitian ini bertujuan untuk memberikan wacana terhadap para peneliti yang tertarik dengan bidang pragmatik untuk bisa melihat bahwa dengan adanya penggunaan beberapa variasi Bahasa yang dituturkan oleh suatu komunitas penutur suatu Bahasa dapat mencerminkan suatu bentuk sistem kesantunan serta budaya yang dianut oleh anggota komunitas penutur Bahasa tersebut, dalam hal ini, komunitas orang tua Tionghoa Surabaya di TBI Surabaya.

\section{LANDASAN TEORI}

\section{Sistem Kesantunan}

Dalam bukunya, Scollon dan Scollon (2001) merumuskan tiga konsep besar tentang kesantunan yang disebut sebagai sistem kesantunan penghormatan (deference politeness system), sistem kesantunan solidaritas (solidarity politeness system), dan sistem kesantunan hierarkis (hierarchical politeness system). Dalam konsep sistem kesantunan yang pertama yaitu sistem kesantunan penghormatan, Scollon dan Scollon (2001) mendefinisikannya sebagai suatu kesantunan yang mana peserta tutur dianggap sama atau hampir sama tetapi saling memperlakukan diri mereka sendiri dalam jarak. Karakteristik sistem ini adalah: 1) simetris (-P) tidak adanya pengaruh posisi atau status sosial yang signifikan sehingga para peserta tutur melihat diri mereka masing-masing dalam posisi/tingkat sosial yang sama; 2 ) adanya pengaruh jarak $(+D)$ yang signifikan sehingga masing-masing dari peserta tutur menggunakan strategi independen dalam berkomunikasi dengan peserta tutur yang lain. Orang dapat mendapati kesantunan penghormatan di mana saja sistem itu berjalan secara egaliter tetapi para peserta tutur tetap mempertahankan jarak penghormatan dari masing-masing. Contoh dari sistem kesantunan penghormatan ini adalah ketika dua profesor yang bertemu dalam satu kesempatan dengan latar belakang universitas yang berbeda akan cenderung menyapa satu sama yang lain dengan sebutan Prof. dan kemudian diikuti dengan nama belakang dari masing-masing profesor tersebut. Penggambaran tentang sistem kesantunan penghormatan dapat dilihat di bagan berikut ini: 


\section{Peserta Tutur $1<=======$ Strategi Indenpenden=======> Peserta Tutur 2 \\ $[+\mathrm{D}=$ Jarak yang signifikan antara peserta tutur $]$ \\ Bagan 1. Sistem kesantunan penghormatan.}

Sistem kesantunan yang kedua adalah sistem kesantunan solidaritas dapat ditemukan pada suatu kondisi ketika dua sahabat dekat saling melakukan percakapan mereka memperlihatkan sebuah contoh sistem solidaritas muka (Scollon dan Scollon, 2001). Tidak ada perasaan dan juga perbedaan kuasa (-P) atau jarak (-D) di antara mereka. Seseorang dapat menemukan kesantunan solidaritas di mana saja sistem itu berjalan secara egaliter dan para peserta tutur merasa atau mengekspresikan kedekatan satu dengan yang lain dengan menggunakan strategi pelibatan diantara peserta tutur. Persahabatan di antara kolega dekat sering dikategorikan ke dalam sistem solidaritas. Berikut adalah penggambaran bagan dari sistem kesantunan solidaritas:

Peserta Tutur $1<=$ Strategi Pelibatan $=>$ Peserta Tutur 2

$[-\mathrm{D}=$ tidak adanya jarak antara peserta tutur $]$

Bagan 2. Sistem kesantunan solidaritas.

Sistem kesantunan ketiga yang dirumuskan oleh Scollon dan Scollon (2001) adalah sistem kesantunan hierarkis. Dalam system kesantunan ini, para peserta tutur mengetahui dan menghormati perbedaan sosial yang menempatkan seseorang dalam posisi atas (superordinate) dan yang lain di bawah (subordinate). Contoh dari sistem kesantunan yang ketiga ini dapat digambarkan ke dalam situasi komunikasi sebagai berikut: ada atasan yang sedang berbicara dengan bawahannya. Karakteristik utama dari sistem ini adalah perbedaan status (power), untuk itu perlu menggunakan tanda +P. Dalam sistem muka semacam itu, hubungan yang ada adalah hubungan asimetris. Orang yang superordinate (atasan) atau pada posisi yang tinggi menggunakan strategi pelibatan dalam berbicara "ke bawah". Orang dalam posisi subordinate (bawahan) atau posisi lebih bawah menggunakan strategi independen dalam berbicara "ke atas". Memanggil seseorang dengan nama akhir dan gelar (Tuan Martin, misalnya) adalah strategi independen. Sedangkan ketika seseorang memanggil yang lainnya dengan namanya saja tanpa gelar (Bambang, misalnya) tergolong dalam strategi pelibatan. Secara singkat, karakteristik dari sistem kesantunan hierarkis adalah sebagai berikut: 1) asimetris $(+\mathrm{P})$ peserta tutur melihat diri mereka masing-masing dalam posisi sosial yang tidak sama dan 2) penggunaan strategi pelibatan yang dilakukan oleh peserta tutur yang lebih "tinggi" dan penggunaan strategi independen yang dilakukan oleh peserta tutur yang lebih "rendah". Penggambaran dari sistem kesantunan hierarkis dapat dilihat lebih lanjut di bagan berikut ini: 
Peserta Tutur 1

(Strategi Pelibatan)

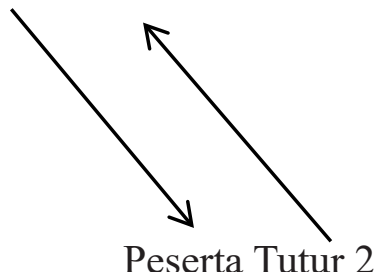

(Strategi Independen)

Bagan 3. Sistem kesantunan hierarkis.

\section{Bahasa, Budaya dan Pikiran}

Bahasa, budaya, dan pikiran memiliki suatu hubungan yang mampu menunjukkan suatu realita dalam kehidupan seseorang. Kramsch(1998, hal. 3), misalnya, menekankan bahwa salah satu hubungan penting antara bahasa, budaya, dan pikiran, adalah bahwa bahasa mampu menunjukkan realitas budaya. Dalam hal ini, gagasan terhadap suatu keadaan atau fakta, pemikiran, cara pandang suatu masyarakat, sikap, kepercayaan bisa disampaikan oleh pengguna bahasa melalui bahasa yang digunakannya. Jika dikaitkan lebih dekat lagi dengan aspek budaya, Boas (dalam Ahearn, 2012, hal. 66) menyatakan bahwa suatu bahasa tertentu yang digunakan oleh suatu masyarakat cenderung mencerminkan praktik-praktik budaya masyarakat itu sendiri. Contohnya, masyarakat Jawa memiliki banyak istilah tentang 'nasi', yaitu pari, gabah, beras, sego, upo, dan karak. Tentu saja ini berbeda dengan konsep 'nasi' yang dimiliki oleh masyarakat Inggris, yang hanya mengenal istilah rice saja. Ini menunjukkan bahwa dalam masyarakat Jawa, ada praktik-praktik budaya yang berkaitan dengan 'nasi' yang lebih kompleks dibandingkan dalam masyarakat Inggris. Banyaknya istilah yang berkaitan dengan 'nasi' dan dilihat dari makna tiap istilahnya, mencerminkan bahwa masyarakat Jawa memiliki praktik-praktik budaya tnetang 'nasi' mulai dari praktik yang berhubungan dengan pertanian hingga pengolahannya.

\section{METODE PENGUMPULAN DAN ANALISIS DATA}

Dalam penelitian ini, penulis bermaksud mengkaji sistem kesantunan yang digunakan oleh komunitas orang tua murid Tionghoa Surabaya di TBI Surabaya serta bentuk-bentuk penggunaan bahasanya yang merefleksikan budaya Tionghoa Surabaya sendiri. Metode yang digunakan dalam penelitian ini bersifat kualitatif. Objek penelitian yang digunakan dalam penelitian ini adalah berupa data deskriptif tentang kata-kata tertulis maupun lisan yang mencerminkan perilaku dari objek penelitian yang sedang diteliti (Wirjokusumo, 2009). Creswell (2007) juga menambahkan bawa dalam 
penelitian kualitatif, peneliti cenderung mengumpulkan data dari objek penelitian mengalami permasalahan secara langsung. Denzin \& Lincoln (dikutip dalam Creswell, 2007, hal. 36) juga menekankan bahwa peneliti yang menggunakan metode kualitatif cenderung mempelajari hal-hal yang berkaitan dengan objek penelitiannya dalam lingkungan yang sebenarnya diharapkan mereka akan mampu menginterpretasikan fenomena yang ada di objek penelitian dengan baik. Sehingga, penulis merasa bahwa metode kualitatif sangat sesuai dengan penelitian ini mengingat objek penelitian adalah komunitas orang tua murid Tionghoa Surabaya di TBI Surabaya. Dalam hal ini, data diambil langsung dari tuturan subjek penelitian tersebut di tempat mereka biasa berkumpul.

Data dalam penelitian ini telah dikumpulkan melalui penerapan metode interaktif. Melalui penerapan metode ini, peneliti memiliki keterlibatan langsung dengan objek penelitian. Teknik yang digunakan adalah observasi dengan melakukan perekaman percakapan objek penelitian tanpa diketahui oleh objek penelitian. Penggunaan teknik observasi ini pada dasarnya merupakan konsekuensi dari sumber data yang digunakan dalam penelitian ini, yaitu informan. Observasi dan perekaman percakapan diantara para informan dilakukan guna mendapatkan data yang tidak dibuat-buat dan bersifat natural.

Sedangkan penerapan teknik analisis data dilakukan dengan cara melakukan pengelolaan data yang telah didapatkan kemudian disaring kembali sesuai dengan tujuan penelitian ini. Setelah melakukan penyaringan data, penulis menampilkan data yang dirasa relevan kemudian dianalisis secara mendalam berdasarkan teori sistem kesantunan dari Scollon dan Scollon (2001) serta bagaimana dari sistem kesantunan tersebut dapat merefleksikan budaya dari masyarakat Tionghoa Surabaya sendiri. Setelah melakukan analisis dari data-data yang telah didapatkan, penulis kemudian membuat suatu kesimpulan yang ditarik dari analisis-analisis data yang ada.

\section{ANALISIS DATA DAN PEMBAHASAN}

Dalam bagian ini, penulis akan membahas pola komunikasi yang terjadi dalam percakapan antara informan. Setelahnya penulis akan menentukan faktor-faktor apa saja yang mempengaruhi pola komunikasi yang terjadi. Ketika telah mengetahui pola dan juga faktor-faktor yang mempengaruhi komunikasi tersebut, peneliti kemudian menentukan strategi kesantunan apa yang digunakan oleh para informan. Setelah itu, barulah penulis akan menentukan jenis sistem kesantunan apa yang dianut oleh komunitas orang tua murid Tionghoa Surabaya di TBI Surabaya melalui penerapan teori sistem kesantunan dari Scollon dan Scollon (2001). Selanjutnya, penulis berusaha mengungkapkan bentuk-bentuk penggunaan bahasa dari subjek penelitian 
ini yang kemudian dapat dilihat dari jenis-jenis pemarkah linguistik yang digunakan. Diharapkan, setelah menemukan bentuk tersebut, penulis dapat melihat refleksi budaya yang terkandung dalam penggunaan atau pengaplikasian bahasa tersebut dalam komunikasi antar penutur bahasa tersebut. Analisis data yang lebih mendalam dari fenomena yang dikaji dalam penelitian ini dapat dilihat ke dalam bagian-bagian berikut:

Pola Komunikasi dari Komunitas Orang Tua Murid Tionghoa Surabaya di TBI

\section{Surabaya}

Berikut adalah percakapan antara informan yang terjadi di lobby dua TBI (The British Institute) Surabaya ketika para informan sedang menunggu anak-anaknya kursus bahasa Inggris.

Percakapan 1

(01) P1: He me, Nathan bukane wayahe mbayar les yo?

(02) P2: Iyo ta, ko?

(03) P1: Iyo wong aku lagek mbayar les e Jojo kok

(04) P2: Tenanan ta ko?

(05) P1: Le piye to me, Nathan mbek Jojo lak sak kelas to, ayo ndang dibayar lumayan lo oleh potongan $15 \%$. Aku oleh potongan si ceng tapi terakhir mbayare hari iki.

(06) P3: Deloken ta ce Maria iku, dikandani ko John gak percoyo, wong anak-anake lo

sak kelas lak yo otomatis tanggal mbayar les e lak podo ae ya to?

(07) P4: Mbuh Maria iku, dikandani sek tekok ae, ndang dibayar kuwi lo les e anake. Ha ha ha ha...

(08) P5: Ancen ngunu kuwi, Maria lak ga percoyoan... Hahahahaha....

(09) P2: He menengo kabeh jok melok-melok haha..

(10) P1: Ndang me, lumayan lo si ceng potongane, soale lek meme bayar lewat tanggal saiki engkuk harga normal dadie.

(11) P2: Hi opo ae to ko John, juaji kok ancen opo-opo diitungi, aku sante ae mene lak isok to ko wong sek dua minggu maneh ae kok kelase Nathan ganti level.

(12) P3: Ngomongo ae nggak nggowo duit saiki atek ngomong sante ce. Hahahaha.

(13) P2: Jok mayak yo Tan, amsyong kok ancen, tak tutuk engkuk hahahaha...

Kutipan percakapan di atas merupakan percakapan diantara lima informan yang digunakan dalam penelitian ini. Mereka merupakan orang tua murid di TBI Surabaya dan semuanya merupakan keturunan Tionghoa. Mereka lahir dan besar di Surabaya. P1 (penutur 1) merupakan seorang pria dan berprofesi sebagai dokter gigi, P2 merupakan seorang wanita dan memiliki usaha catering, P3 merupakan seorang 
wanita dan memiliki profesi sebagai dokter spesialis anak, P4 merupakan seorang pria dan berprofesi sebagai legal manager di salah satu perusahaan swasta di Surabaya dan P5 merupakan wanita yang berprofesi sebagai ibu rumah tangga.

Dalam percakapan 1, terlihat banyaknya penggunaan sisipan kata yang berasal dari dialek Hokkien dari bahasa Mandarin meskipun bila diperhatikan secara menyeluruh terdapat pencampuran antara penggunaan bahasa Jawa Ngoko, bahasa Indonesia dan dialek Hokkien. Kata sapaan kekerabatan seperti kata 'me - meme' dan 'ko - koko' digunakan untuk menekankan identitas para informan sebagai orangorang Tionghoa. Selain penggunaan sapaan kekerabatan, terdapat pula penggunaan perhitungan angka seperti 'si ceng' yang berarti empat ratus ribu. Penggunaan katakata seperti 'juaji' yang berarti pelit dan 'amsyong' yang berarti sial juga turut dimunculkan ke dalam tuturan informan untuk mempertegas identitas mereka sebagai orang Tionghoa. Hal ini bisa terjadi juga karena mereka ingin menunjukkan solidaritas kepada sesama anggota masyarakat etnik Tionghoa dengan cara menghadirkan sisipansisipan kata yang diserap langsung dari dialek Hokkien, Mandarin.

Perilaku yang dicerminkan melalui percakapan diatas adalah sebuah fenomena penggunaan kode linguistik yang bukan terjadi secara acak dan kebetulan. Masingmasing penutur secara sadar menggunakan sisipan-sisipan kata serapan dialek Hokkien, Mandarin dengan pencampuran bahasa Jawa Ngoko khas Surabaya yang terkesan egaliter untuk menunjukkan solidaritas yang ada di dalam komunitas tersebut. Dalam hal ini, hasil dari penelitian ini juga ditemukan pada penelitian Sartini (2007) yang menyatakan bahwa terdapat banyak sisipan penggunaan kata serapan Bahasa Mandarin dalam praktik komunikasi masyarakat Tionghoa di Surabaya. Hal ini bisa terjadi karena adanya usaha dari komunitas penutur tersebut untuk bisa terlihat berbeda dari masyarakat penutur lainnya di Surabaya, dalam hal ini, masyarakat penutur Bahasa Jawa sebagai penutur dominan di wilayah Surabaya.

Berikut adalah contoh percakapan yang juga terjadi di dalam komunitas orang tua murid Tionghoa Surabaya di TBI Surabaya ketika mereka sedang berbincangbincang di lobby dua dan banyak membicarakan makanan ringan yang baru ada di kantin TBI Surabaya.

Percakapan 2

(01) P3: Ce Tasya, cece wes coba pie susu ambek roti sing ndek kantin ta? Ketoke anyar yo?

(02) P5: Lo onok jajan anyar ta ndek kantin? Tak kiro mek onok micin tok ndek kunu...

hahahahaha...

(03) P3: Temenan ce, aku lagek nyoba lo iki, tenan haucek ambek murah sisan, 
koyoke buatan

rumahan iki.

(04) P5: Iyo ta? Piroan me?

(05) P3: Sitoke murah ce mek lak ceng lo, iku isok milih sing roso coklat opo sing original. Seng

rotine yo onok sing go ceng, lak ceng ambek seng roso keju mayo sosis kuwi cit ceng

ce, ndang cobaen. Laris koyoke lagek didekek wes kare sitik.

(06) P5: Wah lumayan yo me, onok variasi tibakno. Sakno anak-anake kene lek njajane ciki-ciki

lek onok roti opo pie kuwi kan pilihane luwe sehat.

(07) P3: Iyo ce, cobaen pokoke. Haucek tenan kok aku iki tak borong tuku 10 langsung hahahahaha..

(08) P5: Iku awakmu sing nggragas ancene me.. hahahaha....

Percakapan 2 di atas merupakan percakapan yang terjadi antara dua informan dalam penelitian ini yang sedang membicarakan tentang menu makanan ringan baru yang ada di kantin TBI Surabaya. Bila diperhatikan, penggunaan bahasa antara P3 dan P5 sama-sama menggunakan tata bahasa yang sama yaitu bahasa Jawa Ngoko yang kemudian menjadi sedikit berbeda dengan bahasa Jawa yang dituturkan oleh masyarakat Jawa pada umumnya. Basaha Tionghoa Surabaya kental sekali dengan pencampuran dialek hokkien, Mandarin ke dalam tuturan si penutur bahasa tersebut. Dalam hal ini, P3 dan P5 berusaha untuk tidak menjaga jarak satu sama lain dengan menggunakan bahasa Jawa khas Surabaya yang terkesan egaliter sehingga tidak terjadi jarak dalam percakapan P3 dan P5. Sisipan-sisipan dialek Hokkien, Mandarin yang ditemukan dalam percakapan tersebut juga menambah kuat solidaritas yang terjadi di antara P3 dan P5. Mereka ingin menunjukkan bahwa mereka berasal dari kelompok etnik yang sama. Hasil penelitian ini juga sejalan dengan hasil penelitian sebelumnya seperti Sartini (2007) dan Jauhari \& Susanto (2014). Kedua penelitian sebelumnya juga menemukan bahwa banyaknya penggunaan sisipan kata serapan Bahasa Mandarin ke dalam komunikasi komunitas Tionghoa. Dalam hal ini, sisipan-sisipan kata tersebut juga cenderung digunakan untuk menunjukkan rasa solidaritas yang tinggi kepada sesama anggota komunitas penutur tersebut seperti penyematan kata-kata kerabat, atau kata-kata yang dekat dengan aktivitas komunitas penutur tersebut seperti mata uang (kebanyakan dari komunitas Tionghoa berprofesi sebagai pedagang). Pernyataan ini didukung oleh pendapat dari Boas (dalam Ahearn, 2012, hal. 66) bahwa suatu bahasa tertentu yang digunakan oleh suatu masyarakat cenderung mencerminkan praktikpraktik budaya masyarakat itu sendiri. Dalam hal ini, masyarakat Tionghoa Surabaya 
yang seringkali menyisipkan kata-kata serapan dialek Hokkien, Mandarin dalam pembicaraan sehari-hari mereka juga sangat dekat dengan aktivitas yang dilakukan oleh masyarakat penutur ini. Dalam hal ini, banyak dari masyarakat Tionghoa Surabaya yang berprofesi sebagai wirusahawan, pebisnis atau pedagang sehingga sematan katakata yang berkaitan dengan mata uang sering ditemukan di dalam komunikasi seharihari mereka.

Hal ini tentu saja merupakan fenomena penggunaan kode linguistik yang unik dan sangat menarik, komunikasi antara orang tua murid yang berasal dari etnik yang sama menggunakan kode linguistik yang sama dan berusaha untuk tidak menggunakan kode linguistik yang berbeda sehingga terjadi hubungan yang simetris di antara kedua penutur tersebut. Selanjutnya, fenomena penggunaan kode linguistik yang terjadi dalam percakapan 2 menunjukkan bahwa adanya suatu eksistensi keseteraan yang ingin ditampilkan ke dalam penggunaan bahasa para penutur tersebut tanpa meninggalkan unsur-unsur pemersatu mereka yaitu penggunaan dialek Hokkien, Mandarin sebagai identitas penutur sebagai komunitas Tionghoa Surabaya.

\section{Faktor-Faktor Pengaruh Penggunaan Tuturan Komunitas Orang Tua Murid Tionghoa Surabaya di TBI Surabaya \\ Faktor Jarak (-D)}

Seperti yang telah digambarkan di dalam dua percakapan di atas, fenomena penggunaan kode linguistik yang terjadi di dalam komunitas orang tua murid Tionghoa Surabaya di TBI Surabaya cenderung tidak memiliki jarak yang berarti. Dalam hal ini, semua informan yang terlibat dalam penelitian ini tidak menunjukkan adanya jarak sosial yang berarti terjadi di antara masing-masing informan. Penggunaan kode linguistik yang ada cenderung terlihat seragam. Pemilihan penggunaan bahasa Jawa Ngoko yang menjadi ciri khas masyarakat Surabaya yang terkesan egaliter kemudian diberikan sisipan-sisipan kata serapan dari bahasa dialek Hokkien, Mandarin kemudian menjadi penanda bahwa bahasa yang digunakan diantara informan tersebut adalah sama.

Penggunaan bahasa yang sama tersebut menjadi pemarkah linguistik yang menandakan bahwa adanya hubungan yang simetris diantara para informan. Hal tersebut diperjelas dengan tuturan-tuturan yang dicucapkan oleh para informan yang sedikit terkesan kasar namun justru hal inilah yang membuat tidak adanya jarak antara satu informan ke informan yang lain. Hal ini akan menjadi berbeda apabila informan yang diteliti tidak memiliki kedekatan emosional yang cukup baik. Bukan tidak mungkin ujaran-ujaran yang dituturkan dengan menggunakan bahasa Jawa Ngoko tadi akan menjadi hal yang dipandang tidak sopan apabila informan-informan tersebut 
tidak saling mengenal. Selain itu, penggunaan sisipan kata serapan dialek Hokkien, Mandarin seperti 'cece', 'koko', 'meme', 'amsyong', 'juaji', 'lak ceng', dan 'haucek' juga menipiskan jarak yang ada diantara para informan oleh karena latar belakang etnisitas yang sama. Penggunaan kata-kata tersebut justru membantu mendekatkan hubungan antara informan karena dapat menimbulkan rasa empati di antara informaninforman tersebut.

\section{Faktor Kuasa (-P)}

Tidak adanya kuasa yang terjadi dalam kedua percakapan di atas juga menjadi faktor penentu dalam mengklasifikasikan jenis strategi kesantunan apa yang sedang dianut oleh komunitas orang tua murid Tionghoa Surabaya tersebut. Dalam hal ini, meskipun para informan berasal dari latar belakang profesi yang berbeda-beda, tidak terjadi suatu hubungan yang dinilai asimetris berdasarkan dari tuturan-tuturan para informan tersebut. Kedekatan yang telah terjalin menjadi salah satu faktor yang kuat yang akhirnya menipiskan pandangan informan tersebut tentang status sosial yang dimiliki masing-masing informan.

Dalam hal ini, para informan tidak lagi memandang status sosial yang berbeda sebagai suatu faktor yang harus diperhatikan dalam menggunakan bahasa mereka. Eksistensi dari pencampuran bahasa Jawa Ngoko dengan dialek Hokkien, Mandarin yang diujarkan oleh para informan tersebut menjadi bukti bahwa tidak adanya kuasa yang bermain di dalamnya. Mereka cenderung menggunakan bahasa yang terkesan egaliter (tidak adanya jarak yang terjadi karena perbedaan status sosial). Hal ini juga menunjukkan bahwa adanya solidaritas yang telah tercipta diantara anggota komunitas tersebut.

\section{Strategi Kesantunan Komunitas Orang Tua Murid Tionghoa Surabaya di TBI Surabaya}

Setelah melakukan penentuan faktor-faktor apa saja yang menjadi pemicu ujaran-ujaran yang dituturkan oleh para informan dalam studi ini, penulis kemudian akan menentukan strategi kesantunan apa yang digunakan dalam komunitas orang tua murid Tionghoa Surabaya ini. Seperti yang telah dijelaskan dalam bagian sebelumnya, tidak adanya jarak dan kuasa yang terjadi dalam percakapan di antara para informan menjadi satu pertanda penting dalam menentukan strategi kesantunan apa yang digunakan oleh komunitas tersebut. Dalam hal ini, strategi kesantunan yang dilakukan oleh masing-masing informan adalah strategi pelibatan. Para informan tidak menunjukkan suatu hubungan yang asimetris dari satu informan ke informan lain. Mereka cenderung menunjukkan penggunaan strategi yang sama dan penggunaan 
bahasa yang seragam pula dengan adanya pencampuran bahasa Jawa Ngoko, bahasa Indonesia dan dialek Hokkien, Mandarin ke dalam percakapan yang terjadi.

Oleh karena itu, penulis merasa bahwa strategi pelibatan adalah strategi kesantunan yang paling tepat dalam mendeskripsikan dua percakapan yang terjadi di dalam komunitas orang tua murid Tionghoa Surabaya di TBI Surabaya. Seluruh informan menunjukkan jarak yang sangat tipis dan mereka tidak terlalu memperhatikan faktor perbedaan status sosial, gender, maupun latar belakang profesi yang bervariasi sebagai faktor utama dalam menentukan penggunaan bahasa apa yang pantas untuk dituturkan ke sesama informan tersebut. Hal ini terjadi karena adanya rasa solidaritas diantara informan yang merasa sudah dekat secara emosional dan terkesan seperti memiliki ikatan keluarga meskipun mereka bukan saudara kandung. Hal ini sejalan dengan pernyataan dari Scollon dan Scollon (2001) yang menyatakan bahwa strategi pelibatan digunakan oleh masing-masing anggota komunitas penutur untuk menghilangkan jarak di antara masing-masing anggota komunitas yang bisa jadi berbeda status sosial namun masih memiliki kesamaan seperti kesamaan etnis, asal-muasal, dan lain sebagainya. Sehingga, dengan tidak adanya jarak yang timbul di antara mitra tutur dan lawan tutur membuat suatu kedekatan secara emosional di antara penutur Bahasa tersebut. Selain itu, kedekatan yang tercermin dari tuturan-tuturan yang diujarkan oleh para informan juga dapat dilihat dari latar belakang etnisitas yang ada di setiap diri informan. Mereka semua berasal dari keturunan Tionghoa dan hal ini terbukti dari banyak sisipan-sisipan kata serapan dialek Hokkien, Mandarin sebagai penanda solidaritas yang muncul di setiap diri informan tersebut.

\section{Sistem Kesantunan Komunitas Orang Tua Murid Tionghoa Surabaya di TBI Surabaya}

Setelah menentukan jenis strategi kesantunan yang digunakan oleh komunitas orang tua murid Tionghoa Surabaya di TBI Surabaya, penulis menentukan jenis sistem kesantunan yang dianut oleh komunitas tersebut. Menurut, Scollon dan Scollon (2001) apabila ada terjadi penggunaan strategi pelibatan diantara penutur maka dapat ditentukan bahwa penutur-penutur tersebut menganut sistem kesantunan solidaritas. Hal ini pula yang terjadi di dalam komunitas orang tua murid Tionghoa Surabaya di TBI Surabaya. Dalam komunitas ini, masing-masing informan yang terlibat dalam komunitas tersebut cenderung menggunakan strategi pelibatan sehingga terciptalah hubungan yang simetris diantara para informan.

Dalam sistem kesantunan solidaritas, kita tidak akan menemui adanya perbedaan jarak maupun kuasa yang terjadi di antara penuturnya. Hal ini juga yang terjadi di dalam komunitas yang dijadikan objek penelitian ini. Mereka cenderung 
menghilangkan jarak dan kuasa yang bisa jadi menjadi faktor penentu penggunaan variasi bahasa kepada mitra tuturnya. Namun dalam hal ini, informan dalam komunitas tersebut menggunakan bahasa yang seragam. Mereka menggabungkan penggunaan bahasa Jawa Ngoko yang terkesan menghapuskan jarak sosial bila dituturkan oleh penuturnya dengan penggunaan bahasa Indonesia serta dialek Hokkien, Mandarin sebagai identitas etnik mereka yaitu masyarakat Tionghoa Surabaya. Hal ini didukung dengan argumen dari Scollon dan Scollon (2001) yang mengatakan bahwa dalam sistem kesantunan solidaritas terdapat ciri utama yaitu tidak adanya perasaan dan juga perbedaan kuasa (-P) atau jarak (-D) di antara para penuturnya. Selain itu, seseorang dapat menemukan kesantunan solidaritas di mana saja sistem itu berjalan secara egaliter dan para peserta tutur merasa atau mengekspresikan kedekatan satu dengan yang lain dengan menggunakan strategi pelibatan di antara peserta tutur (Scollon \& Scollon, 2001). Hal ini pula yang telah ditemukan dalam praktek komunikasi komunitas orang tua Tionghoa Surabaya di TBI Surabaya. Dalam hal ini, komunikasi yang terjadi di antara peserta tutur dalam komunitas ini bersifat sangat egaliter dimana tidak adanya jarak antara satu penutur dengan yang lain.

Penggunaan bahasa campuran dari bahasa Jawa Ngoko, bahasa Indonesia dan dialek Hokkien Mandarin juga merupakan cerminan solidaritas yang ingin ditampilkan oleh para informan. Dalam hal ini, mereka ingin menipiskan jarak dan perbedaan kuasa yang mungkin saja ada diantara mereka dengan menerapkan penggunaan bahasa yang sama. Bahasa Jawa Ngoko yang cenderung terdengar kasar dan tidak sopan digunakan mereka untuk menipiskan jarak sosial yang ada diantara mereka. Hal ini pula yang menjadi ciri khas masyarakat Surabaya yang tidak ingin memperlihatkan perbedaan status sosial yang kemudian diwujudkan ke dalam penggunaan bahasanya. Sedangkan penggunaan dialek Hokkien, Mandarin di dalam komunitas orang tua murid Tionghoa Surabaya tersebut menjadi pemarkah linguistik yang kuat dalam menunjukkan sisi solidaritas dari etnik Tionghoa Surabaya. Dalam hal ini, meskipun informan-informan tersebut menggunakan bahasa Jawa Ngoko dalam komunikasinya namun mereka juga tidak melupakan asal etnik mereka yaitu Tionghoa sehingga terdapat banyak sekali sisipan-sisipan kata serapan dialek Hokkien, Mandarin ke dalam percakapanpercakapan yang terjadi. Penggunaan dialek Hokkien, Mandarin juga berfungsi untuk pemarkah linguistik yang membedakan penggunaan bahasa masyarakat komunitas Tionghoa Surabaya dengan cara menggabungkan dialek tersebut ke dalam penggunaan bahasa Jawa Ngoko. Hal ini pula yang ditemukan oleh Sartini (2007) dalam penelitiannya, terdapat banyak sekali peleburan bahasa antara bahasa Jawa Ngoko dan bahasa Mandarin di dalam komunikasi sehari-hari masyarakat Tionghoa Surabaya. 


\section{Bentuk-Bentuk Penggunaan Bahasa Komunitas Orang Tua Murid Tionghoa Surabaya di TBI Surabaya}

Bagian ini berisi tentang analisis bentuk-bentuk penggunaan bahasa yang ada di komunitas orang tua murid Tionghoa di TBI. Berdasarkan tuturan-tuturan yang ditemukan dalam data penelitian ini, refleksi budaya yang ada merupakan hasil akulturasi budaya yang terjadi. Tuturan-tuturan tersebut sangat kental sekali dengan campuran antara penggunaan bahasa Jawa Ngoko serta dialek Hokkien. Untuk tuturan yang mengandung pengaruh bahasa Jawa Ngoko dapat dilihat di kolom berikut:

\begin{tabular}{|c|c|c|}
\hline No. & Tuturan & Makna \\
\hline 1. & Piye & Bagaimana \\
\hline 2. & Iki & Ini \\
\hline 3. & Deloken & Diberitahu \\
\hline 4. & Dikandani & Tanya \\
\hline 5. & Tekok & Sungguh \\
\hline 6. & Tenanan & Tidak Tahu \\
\hline 7. & Mbuh & Begitu \\
\hline 8. & Ngunu & Apa \\
\hline 9. & Opo & Besok \\
\hline 10. & Mene & Jangan \\
\hline 11. & Jok & Pukul \\
\hline 12. & Tutuk & Jaw \\
\hline
\end{tabular}

Tabel 4.1. Contoh kata-kata serapan bahasa Jawa Ngoko

Beberapa tuturan yang ditemukan merupakan hasil akulturasi dari bahasa Jawa Ngoko dan dialek Hokkien. Contoh dari kata-kata tersebut seperti 'tekok'. Dalam hal ini, kata tersebut tidak benar-benar murni kata dari bahasa Jawa Ngoko namun kata tersebut telah dirubah sedikit agar lebih berterima dan dapat dipergunakan oleh komunitas tersebut. Selain itu, kata-kata yang lain juga merupakan kata serapan bahasa Jawa Ngoko. Penggunaan kata-kata tersebut berkaitan langsung dengan kegiatan mereka sehari-hari. Dalam hal ini, penggunaan kata-kata serapan bahasa Jawa Ngoko tersebut tidak dinilai sebagai suatu penggunaan bahasa yang kurang pantas. Tingkatan Ngoko dalam bahasa Jawa merupakan tingkatan yang terendah. Namun, bahasa Ngoko dipergunakan oleh masyarakat Surabaya sebagai bahasa pemersatu. Tidak ada lagi kelas-kelas yang dibentuk, seseorang tidak harus menggunakan bahasa yang lebih halus apabila sedang berbicara dengan lawan tutur yang statusnya jauh lebih tinggi daripada si penutur. Sehingga, penggunaan bahasa Ngoko disini dipergunakan oleh komunitas orangtua Tionghoa Surabaya untuk mendekatkan masing-masing individu yang berada di komunitas ini agar tidak ada batas di antara masing-masing anggota komunitas tersebut. Nilai-nilai budaya yang dapat direfleksikan dari penggunaan bahasa 
Jawa Ngoko ini adalah masyarakat jawa terkhususnya Surabaya memiliki perbedaan yang cukup signifikan dengan masyarakat Jawa yang lainnya. Bahasa yang digunakan mencerminkan suatu sistem egaliter (tidak ada batasan yang terjadi ketika bahasa tersebut dipergunakan oleh penuturnya). Hal ini pula yang diterapkan oleh komunitas tersebut karena mereka telah lama berbaur dengan masyarakat sekitar sehingga penggunaan bahasa Jawa Ngoko dirasa tepat untuk digunakan dalam mendeskripsikan kegiatan sehari-hari mereka.

Selanjutnya, penulis juga menemukan penggunaan beberapa kata serapan dari dialek Hokkien yang dicampur dengan penggunaan bahasa Jawa Ngoko ketika komunitas orangtua Tionghoa Surabaya tersebut bertutur kata dengan sesama anggota komunitas tersebut. Berikut adalah contoh-contoh kata serapan dialek Hokkien yang ditemukan:

\begin{tabular}{|c|c|c|}
\hline No. & Tuturan & Makna \\
\hline 1. & Me & Adik Perempuan \\
\hline 2. & Juaji & Menjijikkan \\
\hline 3. & Amsyong & Sial \\
\hline 4. & Koko & Kakak Laki-Laki \\
\hline 5. & Haucek & Enak \\
\hline 6. & Go Ceng & Enama Ribu Ribu \\
\hline 7. & Cit Ceng & Tujuh Ribu \\
\hline 8. & Lak Ceng & \\
\hline
\end{tabular}

Tabel 4.2. Contoh kata-kata serapan dialek Hokkien

Beberapa kata yang ditemukan dalam data penelitian ini menunjukkan adanya pencampuran antara bahasa Jawa Ngoko dan dialek Hokkien sebagai bentuk penggunaan bahasa yang menunjukan ciri khas dari komunitas orangtua Tionghoa Surabaya. Seperti yang tertera di Tabel 2, ada 9 kata yang ditengarai merupakan kata serapan dari dialek Hokkien tersebut. Dari penggunaan kata-kata tersebut dapat dilihat refleksi budaya masyarakat Tionghoa sendiri yang sangat erat dengan uang. Pada saat pertama kali mendaratkan kakinya di Indonesia, orang-orang Tionghoa tersebut berada dalam kondisi yang buruk. Mereka tidak memiliki uang sepersen pun untuk bertahan hidup. Melalui kegigihan merekalah, maka mereka mampu merubah status dan kedudukan sosial yang awalnya berada di bawah menjadi naik status sosialnya. Sehingga perjuangan dalam mencari uang ini juga merefleksikan budaya kegigihan serta ketangguhan dari masyarakat tersebut. Sehingga wajar bila mereka memiliki deskripsi yang cukup luas terkait dengan kata-kata yang berhubungan dengan uang seperti go ceng, cit ceng dan lak ceng. 


\section{KESIMPULAN}

Melalui hasil dari penelitian ini, dapat menyimpulkan bahwa sistem kesantunan yang dianut oleh komunitas orang tua murid Tionghoa Surabaya di TBI Surabaya cenderung mengarah ke sistem kesantunan solidaritas. Sistem kesantunan ini dirasa sangat sesuai dengan percakapan-percakapan yang terjadi di dalam komunitas tersebut karena masing-masing informan menggunakan strategi kesantunan yang sama yaitu strategi kesantunan pelibatan. Dengan adanya penggunaan strategi kesantunan ini, para informan berusaha untuk menghapuskan jarak atau kuasa yang ada di antara informan tersebut dengan menggunakan bahasa yang seragam yaitu bahasa campuran yang diserap dari bahasa Jawa Ngoko, bahasa Indonesia dan dialek Hokkien, Mandarin ke dalam percakapan-percakapan yang dilakukan oleh para informan tersebut.

Penggunaan bahasa Jawa Ngoko dimaksud untuk menghapus adanya perbedaan status sosial yang ada diantara informan. Sedangkan, penggunaan sisipan-sisipan kata serapan bahasa dialek Hokkien, Mandarin dimaksudkan untuk meningkatkan rasa solidaritas yang tinggi di masing-masing diri informan. Hal ini juga dilakukan untuk memperlihatkan bahwa mereka berasal dari etnik yang sama yaitu etnik Tionghoa Surabaya. Berkaitan dengan bahasa campuran yang digunakan dengan komunitas tersebut, penggunaan bahasa campuran tersebut digunakan untuk membedakan identitas mereka dari masyarakat Surabaya dengan mereka sebagai masyarakat Tionghoa Surabaya.

Sedangkan refleksi budaya yang dihasilkan dari penggunaan bahasa Jawa Ngoko dan dialek Hokkien ke dalam tuturan komunitas orangtua murid Tinghoa TBI Surabaya adalah ingin menunjukkan sistem egaliter yang juga diberlakukan dalam komunitas mereka melalui penggunaan bahasa Jawa Ngoko serta budaya ketangguhan dan kegigihan yang direfleksikan melalui beberapa penggunaan kata yang berkaitan dengan keuangan. Hal ini berkaitan erat dengan sejarah orang Tionghoa di Surabaya ketika masa-masa penjajahan Belanda di Indonesia.

\section{DAFTAR PUSTAKA}

Ahearn, L. M. (2012). Living Language: An Introduction to Language Anthropology. West Sussex: Willey Blackwell.

Creswell, J. W. (2007). Qualitative Inquiry \& Research Design Choosing Among Five Approaches (2nd ed.). London: SAGE Publications Ltd.

Jauhari, E., \& Susanto, D. (2014). Realisasi Kesantunan Positif dalam Masyakarat Etnik Tionghoa di Surakarta . Prasasti (pp. 61-72). Surakarta: Program Studi 
Robby Andre

S3 Linguistik PPs Universitas Sebelas Maret .

Kramsch, C. (1998). Language and Culture. New York: Oxford University Pres.

Noordjanah, A. (2004). Komunitas Tionghoa di Surabaya (1910-1946). Semarang: MESIASS.

Sartini, N. W. (2007). Varietas Bahasa Masyarakat Cina di Surabaya (Kajian Bahasa Antaretnik). Linguistika, 14(26), 1-18.

Scollon, R., \& Scollon, S. W. (2001). Intercultural Communication: A Discourse Approach. UK: Basil Blackwell Ltd.

Wirjokusumo, I. (2009). Metode Penelitian Kualitatif Bidang Ilmu - Ilmu Sosial Humaniora: Suatu Pengantar. Surabaya: Unesa University Press. 